Forest Ecology and Management, 422(April), 125-136.

https://doi.org/10.1016/i.foreco.2018.04.007

\title{
Structural diversity and dynamics of boreal old-growth forests case study in Eastern Canada
}

\author{
Maxence Martin*1, Nicole Fenton², Hubert Morin' \\ ${ }^{1}$ Département des Sciences fondamentales, Université du Québec à Chicoutimi, 555 boul. de l'Université, \\ Chicoutimi, Québec G7H2B1, Canada \\ 2 Institut de Recherche sur les Forêts, Université du Québec en Abitibi-Témiscamingue, 445 boul. de \\ I'Université, Rouyn-Noranda, Québec J9X 5E4, Canada \\ * Corresponding author: Tel.: +1 5818828651 ; \\ E-mail address: maxence.martin1@uqac.ca
}

Declaration of interests: none

\begin{abstract}
Old-growth stands are considered as key components of boreal forest diversity and their preservation is largely integrated into management plans. However, while the differences between old-growth and young forests have largely been studied, little is known about the diversity of boreal old-growth forests. In managed landscapes, the efficacy of old-growth conservation plans may be reduced depending on how these old-growth forests are considered: as a single, homogeneous and steady-state forest type or as multiple, diverse and dynamic forest types. To fulfil this gap, our objectives were: (1) to create a typology of old-growth boreal structures; (2) to observe how these structures are influenced by environmental and temporal parameters; and (3) to elaborate a succession model of old-growth structural dynamics along temporal and environmental gradients. Seventy-one mature and overmature stands were sampled within a $2200 \mathrm{~km}^{2}$ territory situated in Eastern Canada. Cluster analysis divided the sampled stands into two even-aged types, three transition old-growth types and six true old-growth types. Slope, minimum time since last fire and organic horizon depth were the three environmental and temporal parameters influencing the oldgrowth structures. Paludification-related productivity decline was present in only one old-growth forest type, while the other sites remained productive. These results allowed the creation of three succession models of the dynamics of old-growth stands in the boreal forest of eastern Canada. Boreal stands can undergo numerous structural changes once the old-growth succession process is initiated. An increase in structural diversity when the true old-growth stage is reached, coupled with a variety of secondary disturbance characteristics, favours multiple pathways of structural evolution of these ecosystems over time. Therefore, forest management planning should incorporate this complexity to improve the preservation of old-growth forests in managed territories.
\end{abstract}

Keywords: Old-growth, boreal forest, typology, overmature, succession, conservation 


\section{Introduction}

In forest ecosystems, the old-growth stage can mainly be defined as stands driven by gap-dynamics, with tree mortality caused by secondary disturbances (Hilbert and Wiensczyk 2007; Wirth et al. 2009; Shorohova et al. 2011). In the boreal biome, old-growth forests represent a significant proportion of the natural landscape, regardless of the

differences in disturbance dynamic and species traits among the boreal regions (Östlund et al. 1997; Cyr et al. 2009; Shorohova et al. 2009). Even in territories characterized by short fire cycles, old-growth forests are present due to the random distribution of fire (Bergeron et al. 2002; Bouchard et al. 2008; Cyr et al. 2009). These ecosystems are considered as key habitats of the boreal biome because of their specific structural attributes and their relative stability in comparison to younger stands driven by standreplacing disturbances (Esseen et al. 1997; Kimmins 2003; Fenton and Bergeron 2011).

In managed territories, the choice of harvesting system tends to be determined by the system's short-term profitability and its capacity to generate the maximum possible volume (Haeussler and Kneeshaw 2003), leading to an upper limit of forest rotation, which is generally earlier than the initiation of gap dynamics (Östlund et al. 1997; Bergeron et al. 2002). Furthermore, in some boreal regions, natural disturbances such as fire, windthrow or insect outbreak still occur and compound the impacts of forest harvesting (Armstrong 1999; Bergeron et al. 2006). Consequently, many boreal landscapes are now rejuvenated, simplified and fragmented (Östlund et al. 1997; Etheridge et al. 2006; Boucher et al. 2015). As a result, in heavily managed boreal territories, a significant portion of the erosion of forest biodiversity is linked to the rejuvenation of the forest landscape (Berg et al. 1994; Esseen et al. 1997; Siitonen 2001). In territories where forests are mainly harvested for the first time and where the knowledge about local biodiversity is still scarce, similar losses are expected (Cyr et al. 2009). 
Old-growth forests consequently represent an important issue in forest management, with different planning processes aimed at minimizing the loss of old-growth forests and reducing the impacts when it is harvested (Mosseler et al. 2003; Le Goff et al. 2010). Emphasis has been placed on management models based on the natural disturbance regime (Kuuluvainen 2002; Gauthier et al. 2009) or on the imitation of stand scale natural processes (Vanha-Majamaa et al. 2007; Kuuluvainen 2009). However, these models require a complete understanding of boreal forest natural dynamics at all temporal and spatial scales to be efficient (Kneeshaw and Gauthier 2003; Kuuluvainen 2009; Halme et al. 2013). Each boreal region presents specific characteristics because of particular combinations of climatic factors, disturbance dynamics and species traits (Kneeshaw et al. 2011; Shorohova et al. 2011). Hence, a fine scale understanding of the old-growth dynamics in each boreal region is necessary for efficient management.

Eastern Canada boreal forests fall into this paradigm and a more detailed understanding of old-growth forests is needed. Indeed, most management strategies in this territory consider old-growth forests as a homogeneous group, contrasted uniquely to even-aged stands (Brassard and Chen 2006; Bergeron and Harper 2009). Studies about their diversity and dynamics have focused on the transition processes from even-aged to old-growth forest, typically defined by canopy break-up, the presence of gap dynamics and the progressive replacement of the first cohort (Bergeron and Harper 2009). Once this transition is complete, old-growth forests tend to be viewed as structurally undifferentiated (Nguyen et al. 2002; Harvey et al. 2002). Structural evolution has been observed, however, in boreal old-growth forests undergoing paludification (Lecomte et al. 2006; Bergeron and Harper 2009), a process that is associated with certain soil types and climatic conditions (Lavoie et al. 2005). However, when other soil types and climates are examined, more complex dynamics of old-growth boreal stands can be expected (De Grandpré et al. 2008; Gauthier et al. 2010), as productivity declines due to paludification 
are associated with specific abiotic conditions (Pollock and Payette 2010; Girard et al. 2014; Ward et al. 2014).

Therefore, the analysis of Eastern Canadian boreal old-growth forest structural diversity and the factors explaining its distribution across the landscape is a pertinent case study of a common old-growth forest management problem. A management strategy that aims to maintain old-growth forests, yet which considers them as homogeneous entities, cannot preserve all types of old-growth forest. This recurring issue can be expressed as follows: in a given ecological context, are the old-growth forests a homogeneous and steady-state forest type or multiple, diverse and dynamic forest types? Our study aims to fill this knowledge gap for Eastern Canada by identifying the diversity of old-growth forest structures and their dynamics across a boreal landscape. Specifically, our objectives are: (1) to define a typology of boreal old-growth forests based on their structural attributes; (2)

to observe whether the groups created by the typology can be related to specific environmental characteristics; and (3) to create a succession model of old-growth structural dynamics along both temporal and environmental gradients.

\section{Methods}

\subsection{Study territory}

The study site covers a $2200 \mathrm{~km}^{2}$ area of public land along the southern edge of Lake Mistassini $\left(72^{\circ} 52^{\prime} 36^{\prime \prime} \mathrm{W}, 50^{\circ} 18^{\prime} 50^{\prime \prime} \mathrm{N}\right)$ (Fig. 1). The area is crossed by the Mistassini, the Ouasiemsca and the Nestaocano rivers. The study site is part of the western subdomain of the black spruce (Picea mariana (Mill.))-feather moss bioclimatic domain and belongs to the physiographic region of the Nestaocano River Hills. The topography is essentially characterized by gentle hills and an altitude range from 350 to $750 \mathrm{~m}$. Thick glacial tills are the dominant surface deposits. Rivers and streams are often surrounded by sand 
deposits or vast bogs. Mean annual temperature ranges from -2.5 to $0.0^{\circ} \mathrm{C}$, annual rainfall (rain and snow) from 700 to $1000 \mathrm{~mm}$ and growing season length from 120 to 155 days.

Black spruce and balsam fir (Abies balsamea (L.) Mill.) are the dominant tree species, and they are sometimes found with jack pine, (Pinus banksiana (Lamb.), white spruce (Picea glauca (Moench) Voss), paper birch (Betula papyrifera Marsh.) and trembling aspen (Populus tremuloides) (Bergeron et al. 1998). Timber exploitation in the region began in 1992 and continued at a relatively low level until 2000 when harvest levels increased. This region was chosen for study because it encompasses the spectrum of environmental diversity of the western black spruce-feather moss bioclimatic domain, from poorly-drained valley bottoms situated on organic deposits to well-drained till slopes.

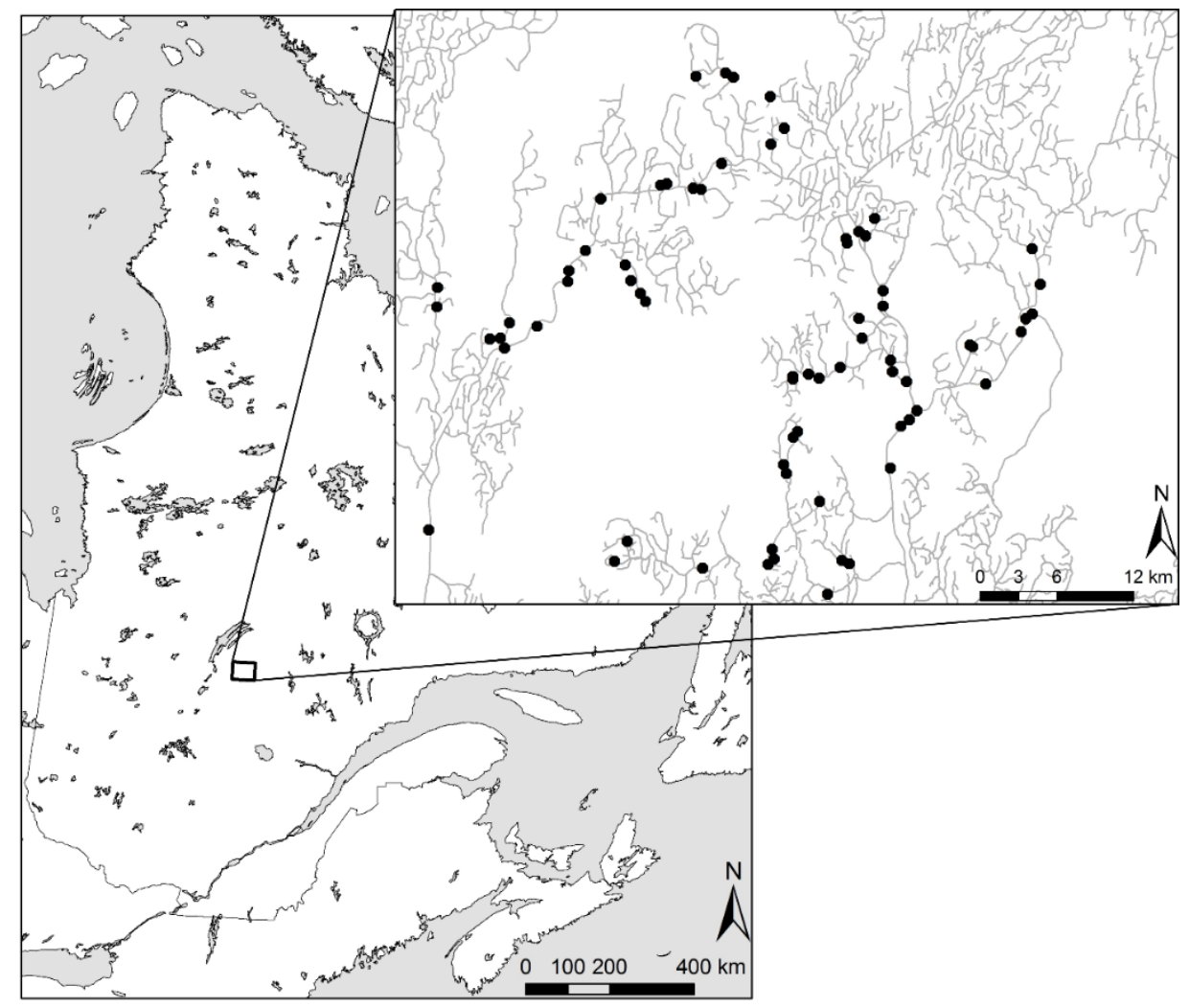

Fig 1. Map of the study territory. The distribution of the sampled stands is indicated by the black dots on the inset map. The grey lines represent the network of forestry roads. 


\subsection{Sampling}

Based on the Québec's Ministry of Forests, Wildlife and Parks (MFWP) ecological classification, this territory can be divided into 19 environmental types; six of these represent over $72 \%$ of the total area. They can be defined by the following Potential vegetation/Slope/Deposit/Drainage associations: Balsam fir - white birch/Medium/Till/Mesic; Black spruce - balsam fir/Medium/Till/Mesic; Black spruce feather moss (BSFM)/Low/Sand/Mesic; BSFM/Low/Till/Mesic; BSFM/Low/Till/Subhydric; BSFM/Low/Organic/Hydric (Blouin and Berger 2004). Because they cover the environmental diversity of the study territory, we selected sites within these six environmental types, with an objective of each having equal sampling intensity. According to Oliver and Larson (1996), old-growth forests can be divided into two stages: transition old-growth (gap dynamics have started, however the stand is still dominated by first cohort trees) and true old-growth (all the trees from the first cohort have disappeared). Following this definition, we attempted to sample the complete successional sequence from mature stands (stands approaching the age of canopy break-up) to true old-growth forests. However, we faced limitations during our site selection. The first limitation is that the dominant boreal tree species in the study area are relatively short-lived (Burns and Honkala 1990), making it impossible to estimate stand ages older than 200 years without using radiocarbon dating (Fenton and Bergeron 2011; Garet et al. 2012). The second is the absence of clear and constant age thresholds between the transition processes, making it impossible to define age classes based on a single transition process. Therefore based on the literature (Uhlig et al. 2001; Bergeron and Harper 2009; Gauthier et al. 2010), we decided to divide our sample stands into three age groups, each one dominated by a single transition process: 80-100 years (maturing), 100-200 years (canopy break-up and beginning of the gap dynamic), >200 years (first cohort disappearance). 
Table 1. Description of the structural, environmental and temporal parameters used in this study.

\begin{tabular}{|c|c|c|c|c|}
\hline Type & Parameter & Acronym & Unit & Description \\
\hline \multirow{14}{*}{$\begin{array}{l}\text { Structural } \\
\text { parameters }\end{array}$} & Tree density & TD & $\mathrm{n} / \mathrm{ha}$ & Number of living merchantable stems per hectare \\
\hline & Sapling density & SD & $\mathrm{n} / \mathrm{ha}$ & Number of living saplings per hectare \\
\hline & Basal area & BA & $\mathrm{m}^{2} / \mathrm{ha}$ & Basal area of the living merchantable trees per hectare \\
\hline & $\begin{array}{l}\text { Basal fir } \\
\text { proportion }\end{array}$ & BFP & $\%$ & Proportion of balsam fir in the basal area \\
\hline & $\begin{array}{l}\text { Coarse woody } \\
\text { debris volume }\end{array}$ & CWD & $\mathrm{m}^{3} / \mathrm{ha}$ & $\begin{array}{l}\text { Calculated according to the Marshall et al. (2000) formula for linear coarse woody } \\
\text { debris sampling }\end{array}$ \\
\hline & Gap fraction & GF & $\%$ & Mean value of the five gap fraction results at each site \\
\hline & Maximum height & $\mathrm{MH}$ & $\mathrm{m}$ & Mean height value of the dominant trees sampled at each site \\
\hline & \multirow{3}{*}{$\begin{array}{l}\text { Weibull's shape } \\
\text { parameter }\end{array}$} & \multirow{3}{*}{ WSP } & \multirow{3}{*}{-} & $\begin{array}{l}\text { Calculated using the Weibull's function of diameter distribution (Bailey and Dell 1973), } \\
\text { defined by the following equation for a random variable X: }\end{array}$ \\
\hline & & & & $f(x)=\left(\frac{a}{b}\right) \times\left(\frac{x}{b}\right) \times \exp \left\{-(x / b)^{a}\right\} ; x \geq 0 ; a>0 ; b>0$ \\
\hline & & & & $\begin{array}{l}\text { This equation is characterized by the shape parameter } a \text {, identified in our study as the } \\
\text { Weibull's shape parameter (WSP), and the scale parameter } b \text {. } \\
\text { WSP } \geq 1.5 \text { represent a Gaussian distribution of the diameters, } 1 \leq \text { WSP }<1.5 \text { an } \\
\text { irregular distribution and WSP }<1 \text { a reverse J-shaped distribution }\end{array}$ \\
\hline & Shannon index & $\mathrm{SI}$ & - & $\begin{array}{l}\text { Calculated according to the Shannon diversity index formula (Shannon and Weaver } \\
\text { 1949) with basal area abundance rather than individual abundance }\end{array}$ \\
\hline & \multirow{3}{*}{$\begin{array}{l}\text { Cohort basal } \\
\text { area proportion }\end{array}$} & \multirow{3}{*}{ CBAP } & \multirow{3}{*}{-} & $\begin{array}{l}\text { Proportion of } \mathrm{N}+1 \text { trees in the basal area, calculated using the Kneeshaw and Gauthier } \\
\text { (2003) formula: }\end{array}$ \\
\hline & & & & $C B A P=-\left(B A_{N+1 \text { trees }}+0.1\right)$ \\
\hline & & & & Where $B A$ is the basal area \\
\hline \multirow{5}{*}{$\begin{array}{l}\text { Environmental } \\
\text { and temporal } \\
\text { parameters }\end{array}$} & $\begin{array}{l}\text { Minimum time } \\
\text { since last fire }\end{array}$ & MTSLF & years & Maximum age value among the ten basal discs \\
\hline & Slope & SL & $\%$ & Mean slope value along the $400 \mathrm{~m}^{2}$ square plot \\
\hline & $\begin{array}{l}\text { Depth of the } \\
\text { organic horizon }\end{array}$ & $\mathrm{DOH}$ & $\mathrm{cm}$ & Mean depth of the organic horizon along the soil profile \\
\hline & $\begin{array}{l}\text { Depth of the } \\
\text { mineral horizon }\end{array}$ & $\mathrm{DMH}$ & $\mathrm{cm}$ & Mean depth of the mineral horizon along the soil profile \\
\hline & Total soil depth & TSD & $\mathrm{cm}$ & Mean total depth of the soil along the soil profile \\
\hline
\end{tabular}

A first survey was realized in order to assess the age of the site, through core sampling of five dominant and codominant trees per sites. Then, seventy-one sites were sampled based on stratified random sampling of forest inventory environmental type and stand age, depending on accessibility. As the study territory is a managed area, the 80-100 years class was the least abundant (12 sites sampled, with at least one site per environmental type), as this class is the most often harvested (Bouchard and Garet 2014). However, gapdynamics do not start exactly 100 years after the fire (Bouchard et al. 2008; Lecomte et 
al. 2006), so we assumed that numerous sites in the 100-200 years class were still evenaged, compensating the lack of sites in the 80-100 years class.

At each site, the centre of the plot was systematically placed $125 \mathrm{~m}$ beyond the stand edge in order to limit edge effects and to avoid bias. Soil and topographic parameters were determined by digging a soil profile at the plot centre and measuring topographic variables with a clinometer. Living trees having a diameter at breast height $(\mathrm{dbh}) \geq 9 \mathrm{~cm}$ (merchantable trees) were sampled in a $400 \mathrm{~m}^{2}$ square plot $(20 \times 20 \mathrm{~m})$, the standard plot size in the Québec forest survey (MFFP 2016). For each individual tree, we noted dbh, vitality (alive, senescent or dead) and position in the canopy (dominant, codominant, intermediary or oppressed), the two last parameters being defined according to the MFWP typology (MRN 2013). We then identified and measured the dbh of all living trees having a dbh $<9 \mathrm{~cm}$ and a height $>1.30 \mathrm{~m}$ (saplings) found in two $100 \mathrm{~m}^{2}$ subplots within the 400 $\mathrm{m}^{2}$ plot. Gap fraction, the ratio between gap length and total transect length (Runkle 1982, Battles et al. 1996), was also measured along five $25 \mathrm{~m}$ long transects starting from the centre of the $400 \mathrm{~m}^{2}$ plot. Gaps were defined as all sections of the transect where the canopy was below the 2/3 height of the dominant trees (Pham et al. 2004) and having a gap length superior to $2 \mathrm{~m}$. This second criterion was included to avoid confusion between actual gaps and the natural separation between tree crowns in these forests. Coarse woody debris (CWD) diameter, where the CWD intersected the transect line, and species was determined along four $20 \mathrm{~m}$ long transects following the edge of the $400 \mathrm{~m}^{2}$ plot, a methodology inspired by Clark et al. (1998). We considered only CWD having a diameter $\geq 9 \mathrm{~cm}$ at the transect intersection and not buried at a depth $>15 \mathrm{~cm}$; CWD buried below this depth was ignored as it was difficult to sample. When a piece of CWD crossed two transects, any second encounter was skipped to avoid double-counting. To determine the minimum stand age, we collected a disc from each base of ten merchantable trees; we sampled a similar number of trees per layer (dominant, codominant, intermediary and 
oppressed) for each site. At least three of these trees were dominant trees and their height was measured once the tree was felled to estimate the maximum stand height.

\subsection{Data analysis}

Discs were air-dried and sanded with progressively finer grade sandpaper. Tree rings were counted along two radii for each disc and the maximum value was considered as the minimum age of the tree. Strong growth-release or growth-reduction events were identified by visual observation and the ring representing the growth-change threshold was determined. The ten rings before and after this threshold were measured with a precision of $0.01 \mathrm{~mm}$ manual Henson micrometer (Fred C. Henson, Mission Viejo, Calif, USA) or a LINTAB measurement table (LINTAB ${ }^{\mathrm{TM}}$, Rinntech, Heidelberg, Germany) along the two radii. Tree ring data were computed using the TSAP-WIN program (Rinntech, Heidelberg, Germany). If the mean change of the two growth measurements was $>50 \%$, it was considered as a significant release or reduction event (Black and Abrams 2003; Fraver and White 2005). These data and the age distribution of the sampled stems were used to determine if these trees belonged to the first or to subsequent cohorts ( $N+1$ cohorts). We considered that all trees belonged to the first cohort when the difference between the youngest and the oldest tree did not exceed 30 years, as this threshold represents the beginning of seed production for black spruce and balsam fir (Burns and Honkala 1990; Viglas et al. 2013), the main late successional species. All the individuals exceeding this 30 years threshold were considered as belonging to the $\mathrm{N}+1$ cohorts. Individuals belonging to the $0-30$ years group were considered as first cohort trees as long as there was no evidence of juvenile suppression or only one tree remained in this group. If one of these criteria was fulfilled, all the trees were considered as belonging to the $\mathrm{N}+1$ cohorts. When the majority of the trees belonged to a single 30 year age class but were mixed with 
individuals more than 30 years older, the older individuals were considered as survivors, and were not classified as first cohort or $\mathrm{N}+1$ cohort trees.

Ten structural parameters and five environmental and temporal parameters were obtained from the sampled data and used for the analysis (Table 1). These ten structural parameters were considered adequate to describe (i) vertical and horizontal variation in the stands (Oliver and Larson 1996; Boucher et al. 2003; Bergeron and Harper 2009), (ii) mortality events and regeneration efficiency (Oliver and Larson 1996; Desponts et al. 2004; Pham et al. 2004), (iii) changes in productivity (Harper et al. 2003; St-Denis et al. 2010), (iv) replacement of shade intolerant species by shade tolerant ones (Bergeron 2000; De Grandpré et al. 2000; Kneeshaw and Gauthier 2003) (v) transition dynamics (Bergeron 2000; Bergeron and Harper 2009; Gauthier et al. 2010), (vi) development of the paludification process (Simard et al. 2007; Ward et al. 2014) and (vii) influence of soil and topographic characteristics on secondary disturbance dynamics and forest succession (Ruel 2000; Gauthier et al. 2010; Messaoud et al. 2014). The Weibull's shape parameter and the CBAP were calculated according to the formulas described in table 1 . The calculation of the Weibull's shape parameter was performed using the EasyFit 5.5 Professional distribution fitting software (Mathwave Technologies). For each site, saplings and merchantable stems were grouped in $2 \mathrm{~cm}$ diameter class in order to improve the fitting function. Statistical analyses were completed using R-software, version 3.3.1 ( $R$ Development Core Team 2016) using the vegan (Oksanen et al. 2017), cluster (Maechler et al. 2017), agricolae (de Mendiburu 2017), FactoMiner (Le et al. 2008) and Imtest (Zeileis and Hothorn 2002) packages applying a p-threshold of 0.05 .

For our first objective of defining a typology, principal component analysis (PCA) was performed using the structural parameters of the 71 sites. The strength of the relationship between each variable and the PCA axis was determined by Pearson's correlation. We then performed a Ward's linkage clustering (Ward 1963) using Euclidean distances to 
determine homogeneous forest types. The parameters used for the clustering were the structural parameters, but scaled to equalize their variance. The optimal number of forest types was determined using average silhouette widths and fusion-level values (Rousseeuw 1987; Borcard et al. 2011). We considered three sites per forest type as a minimum number to provide a relevant ecological analysis. Once the forest types were defined, among-type differences based on their structural, environmental and temporal parameters were determined by Kruskall-Wallis ANOVA by ranks followed by post hoc multiple comparisons of the treatments for the significant results (Fisher's least significant difference). The old-growth stage of each forest type was determined using two of the structural parameters: Weibull's shape parameter (WSP) and cohort basal area proportion (CBAP). WSP represents the diameter distribution of the living trees, from a normal to a reverse J distribution (Bailey and Dell 1973), and CBAP indicates the proportion of $\mathrm{N}+1$ cohort trees in the stand basal area (Kneeshaw and Gauthier 2003). The combination of these two parameters was considered as an efficient indicator of the gap-dynamics in the studied stands, as they describe both the increasing structural complexity and the progressive replacement of first cohort trees expected during the old-growth transition process (Kneeshaw and Gauthier 2003; Brassard and Chen 2006; Hilbert and Wiensczyk 2007). Even-aged stands are defined here as those having a normal diameter distribution. Old-growth stands have an irregular distribution, but this distribution is rarely a true reverse J, especially in black spruce stands (Boucher et al. 2003; Fraver et al. 2008). As such, we used a WSP threshold of 1.5 , with WSP values $>1.5$ representing a normal distribution and WSP values $<1.5$ reflecting an irregular distribution (Bailey and Dell 1973). Transition old-growth stands should have CBAP values >0.3 (Kneeshaw and Gauthier 2003; Brassard and Chen 2006), representing the beginning of the first cohort replacement, while true old-growth stands should have a CBAP value of 1 (total replacement of the first cohort, Oliver and Larson 1996). Consequently, even-aged structures were defined by a 
WSP $\geq 1.5$ and a CBAP $<0.3$, true old-growth structures had WSP and CBAP values of $<1.5$ and 1 , respectively, and transition old-growth structures were represented by all other WSP-CBAP combinations. In this study, structurally even-aged stands are not defined as being old-growth, although with a mean time since the last fire at over 100 years they would have been considered as old-growth in some studies (e.g. Bergeron and Harper 2009).

For our second objective of determining the relationships between forest types and environmental variables, we performed a simple linear regression. Structural parameters of the different forest types were used as dependent variables, and temporal and environmental parameters were the independent variables. Only those independent variables presenting significant differences between forest types and showing no intercorrelations were used. Model assumptions were tested and if they were not fulfilled, the dependant variable was transformed. When transformations were not adequate, the model was considered to be invalid. Finally, our third objective of constructing a successional model was developed using the significantly different parameters of the previous analysis.

\section{Results and discussion}

\subsection{Typology of old-growth forests}

The first three axes of the PCA explained $69.5 \%$ of the total variance of the sites (Fig. 2). All the structural parameters had a significant influence along at least one of the three axes, but seven of them were significant along two or more axes, which emphasizes the intricate interactions between the structural parameters shaping old-growth boreal forests in Eastern Canada. The identification of 11 forest types by cluster analysis underlines this entanglement of boreal oldest structures, as most types overlap to some degree on the PCA biplots. These results illustrate how oldest forest structures are shaped by secondary 

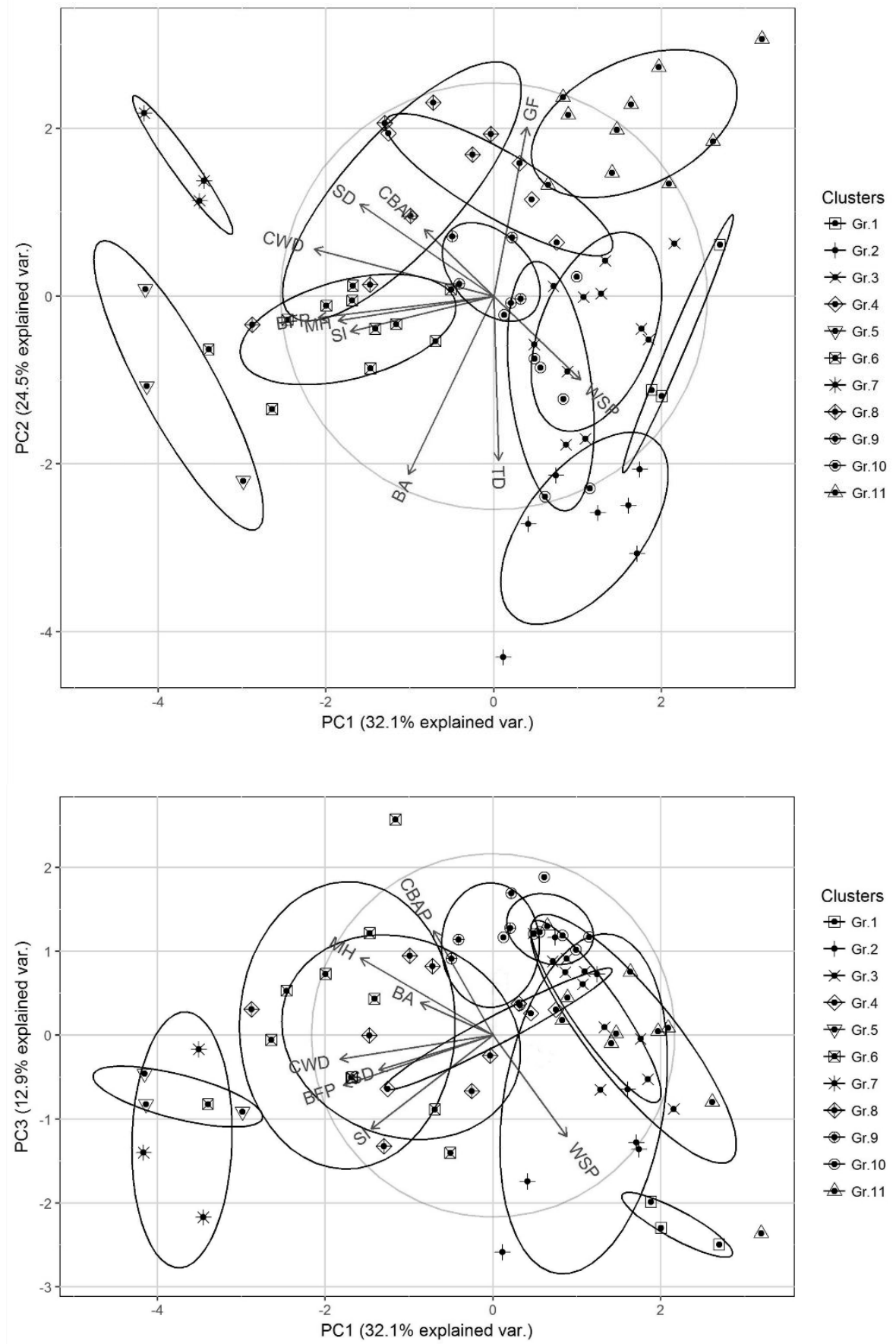

Fig 2. Principal component analysis (PCA) and clustering of the 71 study sites. (a) The biplot of the first and the second axes of the PCA (PC1 and PC2). (b) The biplot of the first and the third axes (PC1 and PC3). Sites belonging to the same cluster are identified by specific symbols surrounding a black dot. Ellipses illustrate cluster distributions along the PCA axes at a 95\% confidence interval around the centroid. Parameters having a significant correlation with an axis are illustrated on the diagram. For codes see Table 1. (Gr.: group). 
Table 2. Mean and standard error (in italics) of the structural parameters for the 11 old-growth forest types defined by hierarchical clustering. Different letters indicate significant differences between forest types at a $p$ value of $\leq 0.05$. For parameter codes, see Table 1.

\begin{tabular}{|c|c|c|c|c|c|c|c|c|c|c|c|}
\hline Parameter & Group 1 & Group 2 & Group 3 & Group 4 & Group 5 & Group 6 & Group 7 & Group 8 & Group 9 & Group 10 & Group 11 \\
\hline \multirow{2}{*}{ TD } & $783.33 \mathrm{bd}$ & $1517.85 a$ & $977.27 \mathrm{~b}$ & $618.75 \mathrm{~cd}$ & $900 \mathrm{bc}$ & 868.18 bc & 891.66 bc & $778.57 \mathrm{~cd}$ & $745 \mathrm{~cd}$ & $1457.14 \mathrm{a}$ & $502.5 \mathrm{~d}$ \\
\hline & 142.15 & 282.36 & 255.79 & 104.83 & 330.71 & 230.24 & 104.08 & 310.04 & 44.72 & 244.4 & 248.17 \\
\hline \multirow{2}{*}{ SD } & $750 \mathrm{~d}$ & $1389.28 \mathrm{~d}$ & $1636.36 \mathrm{~cd}$ & $2787.5 \mathrm{bc}$ & $4150 \mathrm{ab}$ & $2972.72 b$ & $9450 \mathrm{a}$ & $3796.42 \mathrm{ab}$ & $1935 \mathrm{~cd}$ & $1882.14 \mathrm{~cd}$ & 2497.5 bc \\
\hline & 468.37 & 1027.62 & 690.95 & 1654.47 & 482.83 & 1151.97 & 1307.66 & 962.68 & 1567.3 & 880.42 & 1325.67 \\
\hline \multirow{2}{*}{ BA } & $11.6 \mathrm{~cd}$ & 27.67 a & $16.38 \mathrm{~b}$ & $15.18 b c$ & $27.45 \mathrm{a}$ & $21.51 \mathrm{a}$ & $14.9 \mathrm{bc}$ & $15 b c$ & $15.75 \mathrm{bc}$ & $21.93 \mathrm{a}$ & $6.95 \mathrm{~d}$ \\
\hline & 1.93 & 6.43 & 4.88 & 1.44 & 4.81 & 5.38 & 1.91 & 7.68 & 1.67 & 4.73 & 3.3 \\
\hline \multirow{2}{*}{ BFP } & $0 \mathrm{e}$ & 7.46 be & $0.24 \mathrm{de}$ & $0.97 \mathrm{bd}$ & $81.29 a$ & $21.87 \mathrm{a}$ & 54.96 a & $22.53 \mathrm{a}$ & $1.78 \mathrm{~b}$ & $1.4 \mathrm{bc}$ & $0.11 \mathrm{ce}$ \\
\hline & 0 & 14.94 & 0.75 & 1.62 & 11.87 & 8.15 & 5.1 & 26.53 & 1.96 & 1.96 & 0.27 \\
\hline \multirow{2}{*}{ CWD } & $3.78 \mathrm{f}$ & $11.2 \mathrm{f}$ & $26.49 \mathrm{e}$ & $107.76 a b$ & $144.4 a b$ & $106.24 a b$ & $154.77 \mathrm{a}$ & $70.28 \mathrm{bc}$ & $52.31 \mathrm{~cd}$ & $33.11 \mathrm{de}$ & 25.96 ef \\
\hline & 3.66 & 12.61 & 13.77 & 60.58 & 72.47 & 40.01 & 62.94 & 12.55 & 16.42 & 21.77 & 28.56 \\
\hline \multirow{2}{*}{ GF } & $60.41 \mathrm{bc}$ & $38.73 \mathrm{~d}$ & $52.57 \mathrm{bc}$ & $94 \mathrm{a}$ & $35.38 \mathrm{~d}$ & $46.36 \mathrm{~cd}$ & $72.73 a b$ & $95.16 \mathrm{a}$ & $48.16 \mathrm{~cd}$ & $53.95 \mathrm{bc}$ & $93.43 \mathrm{a}$ \\
\hline & 34.28 & 16.4 & 15.33 & 12 & 12.61 & 13.04 & 14.83 & 7.33 & 15.24 & 11.99 & 10.15 \\
\hline \multirow{2}{*}{ MH } & $13.93 \mathrm{e}$ & $16.22 \mathrm{de}$ & $17.84 \mathrm{bd}$ & $20.17 a b$ & $21.76 \mathrm{a}$ & $21.36 \mathrm{a}$ & $19.7 \mathrm{ac}$ & $20.42 a$ & $19.64 \mathrm{abc}$ & $17.81 \mathrm{~cd}$ & $15.02 \mathrm{e}$ \\
\hline & 0.55 & 2.43 & 2.89 & 0.85 & 1.15 & 2.29 & 2.22 & 2.18 & 1.91 & 1.41 & 2.8 \\
\hline \multirow{2}{*}{ WSP } & $1.82 \mathrm{a}$ & $1.54 \mathrm{ab}$ & $1.04 \mathrm{bc}$ & $0.78 d$ & $0.78 \mathrm{~d}$ & $0.8 \mathrm{~d}$ & $0.88 \mathrm{~cd}$ & $0.94 \mathrm{~cd}$ & $0.8 \mathrm{~d}$ & $1.15 \mathrm{ac}$ & $0.98 \mathrm{~cd}$ \\
\hline & 0.16 & 0.66 & 0.2 & 0.12 & 0.17 & 0.48 & 0.12 & 0.17 & 0.06 & 0.22 & 0.19 \\
\hline \multirow{2}{*}{ SI } & $0.24 \mathrm{ab}$ & $0.17 \mathrm{bc}$ & $0.02 \mathrm{e}$ & $0.03 \mathrm{de}$ & $0.28 \mathrm{ab}$ & $0.27 \mathrm{ab}$ & $0.31 \mathrm{a}$ & $0.24 a b$ & $0.12 \mathrm{~cd}$ & $0.03 \mathrm{de}$ & $0.01 \mathrm{e}$ \\
\hline & 0.06 & 0.14 & 0.05 & 0.06 & 0 & 0.11 & 0.05 & 0.08 & 0.1 & 0.04 & 0.03 \\
\hline \multirow{2}{*}{ CBAP } & $0.08 \mathrm{e}$ & $0.11 \mathrm{e}$ & $0.32 \mathrm{e}$ & $0.17 \mathrm{e}$ & $0.46 \mathrm{de}$ & $0.61 \mathrm{~cd}$ & $0.82 \mathrm{ac}$ & $0.86 a b$ & $0.91 \mathrm{ab}$ & $0.95 a$ & $0.65 \mathrm{bd}$ \\
\hline & 0 & 0.09 & 0.16 & 0.1 & 0.35 & 0.29 & 0.3 & 0.18 & 0.09 & 0.09 & 0.37 \\
\hline
\end{tabular}

disturbances that vary in scale, nature and intensity, leading to progressive differentiations rather than abrupt ones (Kneeshaw and Burton 1998; Mosseler et al. 2003). However, the significant results of the Kruskall-Wallis test for all the structural parameters between the forest types (Table 2) highlight their specificities, as despite overlap among forest types, each is defined by a set of distinct characteristics.

This diversity of structures can be difficult to visualize, therefore a typology was constructed based on the two most important parameters for each PCA axis: CWD and balsam fir proportion (BFP) for axis 1, basal area (BA) and gap fraction (GF) for axis 2 and CBAP and WSP for axis 3 (Fig. 3). The importance of the CWD volume and the presence of late-successional species such as balsam fir is consistent with the results of previous studies where these parameters were considered as key elements of old-growth structures (Brassard and Chen 2006; Hilbert and Wiensczyk 2007). Similarly, BA and GF reflect the openness of the canopy, which can be caused by several factors inherent to boreal old-growth dynamics: gap dynamics, secondary disturbances or paludification (Oliver and Larson 1996; Pham et al. 2004; Fenton and Bergeron 2011). These four 


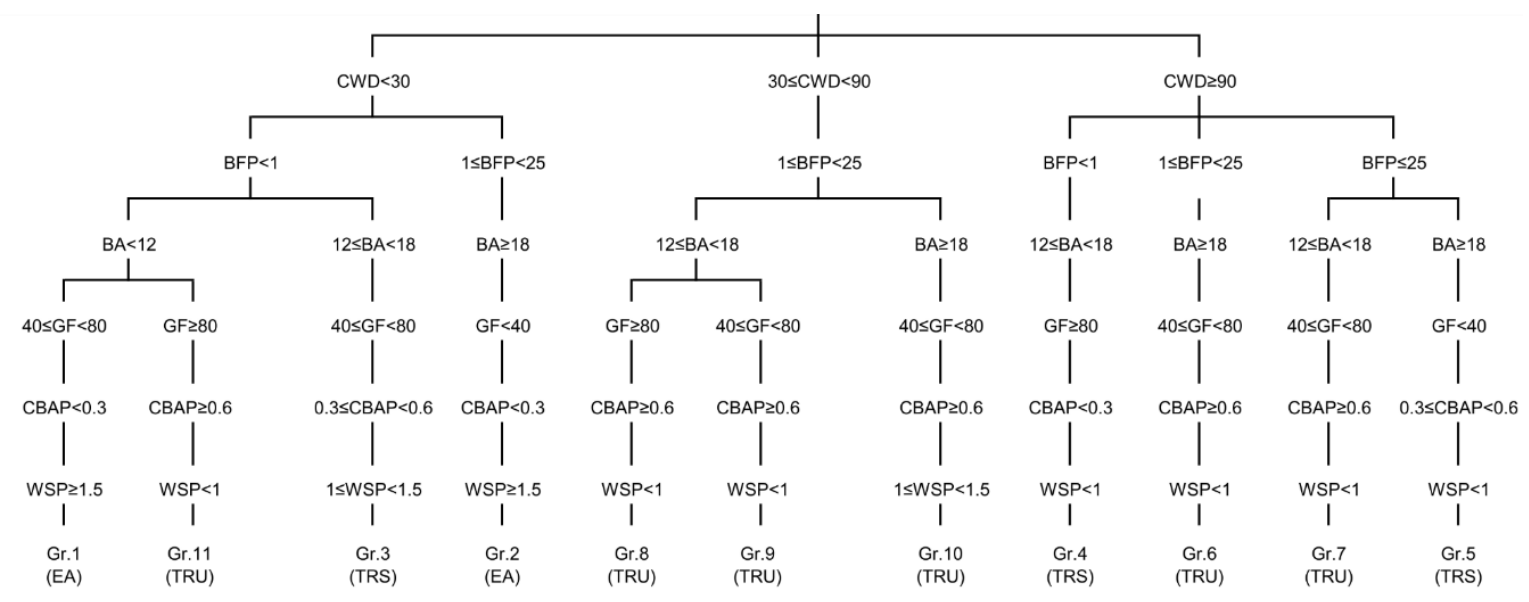

Fig 3. Typology of the old-growth forest types based on structural attributes. The old-growth stage of each forest type is presented under their names in parentheses: EA (even-aged), TRS (transition old-growth) and TRU (true old-growth). CWD: coarse woody debris, BFP: balsam fir proportion, BA: basal area, GF: gap fraction, CBAP: cohort basal area proportion, WSP: Weibull's shape parameter, Gr.: group).

parameters are sufficient to divide our forest types into distinct structural paths, and they are consequently key factors for describing the structural diversity of old-growth boreal forests.

Despite this, CBAP and WSP remain important indicators of old-growth stages and provide insight into the position of the forest types along the old-growth succession process. The forest types having the highest mean CBAP values contained numerous stands with a CBAP value of 1, (true old-growth forests, Oliver and Larson 1996), but none of our forest types had a mean CBAP of 1 . The Eastern Canadian boreal forest is characterized by relatively small changes in stand composition during succession. Indeed, black spruce is both pioneer and a late successional species and shade-intolerant broadleaved species, such as paper birch, are also found at low densities in old-growth stands (Bergeron 2000; Harvey et al. 2002; Gauthier et al. 2010). Similarly, in our forest types, no important changes in stand composition can be observed over time (Appendix A). Then, it seems that the first cohort complete disappearance may not induce significant structural changes. True old-growth structures in Eastern Canadian boreal stands could be reached even when the first cohort has not totally disappeared. In addition, the cohort 
of oldest trees is harder to identify in uneven-aged structures and this implies a possible CBAP underestimation for the oldest stands. For these reasons, we decreased the CBAP threshold from 1 to 0.6 , twice the transition old-growth threshold (Kneeshaw and Gauthier 2003; Brassard and Chen 2006). Thus, we now include stands where the first cohort trees represent a minor part of the living basal area. According to this classification, two of our forest types were even-aged, three were transition old-growth and six were true oldgrowth. As such, our results offer an efficient alternative to the common perception of oldgrowth boreal forests being homogeneous entities.

The presence of forest types representing even-aged structures was expected as the initiation of gap dynamics can occur over a wide age range, especially in black sprucedominated stands (De Grandpré et al. 2000; Uhlig et al. 2001). These even-aged forest types also present a mean MTSLF superior to 100 years, making them old-growth forests according to age-based definitions for Québec's boreal forest (Bergeron and Harper 2009; Cyr et al. 2009). These results are another example of the complexity in consistently defining old-growth forests among and within regions (Wirth et al. 2009; Pesklevits et al. 2011). Group 1 represents open jack pine-black spruce mixtures typical of regularly burned areas (Smirnova et al. 2008) while Group 2 includes dense pure black spruce stands, black spruce-jack pine mixtures and black spruce-balsam fir-white birch mixtures (Appendix A). Therefore, despite their differences in tree composition, even-aged stands are regrouped into two specific structures, apparently discriminated by stand-replacing disturbance dynamics. In contrast, transition old-growth and true old-growth structures are highly variable, confirming that old-growth forests are a key element of landscape structural heterogeneity (Franklin et al. 2002; Harper et al. 2002; Hendrickson 2003). Moreover, in comparison to the even-aged or transition old-growth stages, true old-growth stages present the highest number of specific structures. Structural diversity is expected to increase in the absence of stand replacing disturbance (Franklin et al. 2002). Our results 
confirm this observation for boreal stands in Eastern Canada, as structural richness increased along the old-growth transition process.

\subsection{Influence of environmental and temporal parameters on old-growth} structures

Among the environmental and temporal parameters examined, minimum time since last fire (MTSLF), slope and depth of the organic horizon differed significantly among the forest types (Table 3). MTSLF values ranged from 104 to 254 years (Group1 and Group 9), slope from 2.20 to $32.3 \%$ (Group 11 and Group 5) and depth of the organic horizon to 11.0 to $47.2 \mathrm{~cm}$ (Group 5 and Group 11). As forests are dynamic systems, MTSLF is a key element of boreal forest dynamics, especially during the transition to old-growth where strong structural changes happen within a century (Brassard and Chen 2006; Bergeron and Harper 2009). Slope favours the development of balsam fir in the black sprucefeather moss bioclimatic domain, this species being more present on steep and welldrained sites (Messaoud et al. 2007; Gauthier et al. 2010; Côté 2013). In addition, the higher susceptibility of balsam fir to windthrow compared to black spruce and the competitiveness of balsam fir regeneration in the resulting gaps create a positive feedback of windthrow occurrence, leading to a shift in natural disturbance dynamics (Ruel 2000; Girard et al. 2014). Finally, the depth of the organic horizon is a limiting factor for balsam fir development, and the decrease in productivity caused by the thickening of the organic layer leads to canopy opening and low density structures (Messaoud et al. 2007; Simard et al. 2007; St-Denis et al. 2010). However, the depth of the organic horizon is influenced both by MTSLF and slope (Fenton et al. 2005; Laamrani et al. 2014). Therefore, these last parameters are the principal environmental and temporal factors influencing old-growth structures, while the depth of the organic horizon is the result of their interaction. 
Table 3. Mean and standard error (in italics) of the environmental parameters of the 11 old-growth forest types defined by hierarchical clustering. Different letters indicate significant differences between forest types at a $p$ value of $\leq 0.05$. For parameter codes, see Table 1 .

\begin{tabular}{|c|c|c|c|c|c|c|c|c|c|c|c|}
\hline Parameter & Group 1 & Group 2 & Group 3 & Group 4 & Group 5 & Group 6 & Group 7 & Group 8 & Group 9 & Group 10 & Group 11 \\
\hline \multirow{2}{*}{ MTSLF } & $104 \mathrm{~d}$ & $114.42 \mathrm{~d}$ & $170.45 \mathrm{c}$ & $215.25 a b$ & $160.66 \mathrm{~cd}$ & $177.54 \mathrm{bc}$ & 188.33 ac & $245.28 \mathrm{a}$ & $253.8 \mathrm{a}$ & $248.71 \mathrm{a}$ & $220.9 a b$ \\
\hline & 19.15 & 23.22 & 51.75 & 9.42 & 50.14 & 18.1 & 50.14 & 49.16 & 45.45 & 50.84 & 71.24 \\
\hline \multirow{2}{*}{ SL } & $4.33 \mathrm{de}$ & $7.42 \mathrm{de}$ & $6.36 \mathrm{ce}$ & 10.75 bd & $32.33 \mathrm{a}$ & $14.18 \mathrm{ac}$ & $18.66 \mathrm{ab}$ & $14.14 \mathrm{ac}$ & $5.8 \mathrm{de}$ & 6.85 ce & $2.2 \mathrm{e}$ \\
\hline & 7.5 & 12.34 & 3.9 & 9.21 & 3.05 & 9.56 & 5.03 & 10.57 & 7.66 & 5.58 & 4.58 \\
\hline \multirow{2}{*}{$\mathrm{DOH}$} & 26.66 bd & $20.28 \mathrm{~cd}$ & $35.09 \mathrm{ab}$ & $33.25 \mathrm{ac}$ & $11 \mathrm{~d}$ & $24 \mathrm{bd}$ & $29 \mathrm{ad}$ & $35.85 a b$ & $29.6 \mathrm{ac}$ & $31.85 \mathrm{ac}$ & $47.2 \mathrm{a}$ \\
\hline & 20.2 & 9.49 & 15.2 & 19.55 & 4.58 & 11.61 & 15.09 & 15.74 & 13.95 & 12.58 & 18.34 \\
\hline \multirow{2}{*}{ DMH } & 4.33 & 9.42 & 10.18 & 8 & 15.33 & 20.36 & 16.66 & 7.28 & 9 & 12.85 & 4 \\
\hline & 7.5 & 9.98 & 10.08 & 6,00 & 13.57 & 18.73 & 16.5 & 11.02 & 7.31 & 14.41 & 6.59 \\
\hline \multirow{2}{*}{ TSD } & 31 & 29.71 & 45.27 & 41.25 & 26.33 & 44.36 & 45.66 & 43.14 & 38.6 & 44.71 & 51.2 \\
\hline & 17.69 & 12.89 & 9.88 & 17.7 & 14.97 & 15.53 & 14.01 & 11.81 & 10.85 & 12.13 & 13.7 \\
\hline
\end{tabular}

Regression analysis highlighted the influence of MTSLF and slope on the structural attributes, explaining in part the differences between the forest types (Table 4). Slope significantly influenced two structural attributes: balsam fir proportion (positive) and gap fraction (negative). These results are explained by the more suitable conditions offered by the steepest sites for balsam fir due to better soil drainage (Côté 2013). On less pronounced slopes balsam fir is less present because of frequent fire recurrence or paludification (Messaoud et al. 2007; Smirnova et al. 2008; St-Denis et al. 2010). MTSLF had a significant influence on four parameters: coarse woody debris (positive), Weibull's shape parameter (negative), cohort basal area proportion (positive) and maximum height (positive). These results illustrate the progressive accumulation of deadwood during the old-growth transition process (Sturtevant et al. 1997; Clark et al. 1998), the structural stand complexification because of the replacement of the first cohort (Oliver and Larson 1996; Wirth et al. 2009) and the linear relationship between age and black spruce height (Robichaud and Methven 1993). Moreover, slope and MTSLF influence different structural parameters although without significant interactions between them (Table 4). Because of the specific effects of MTSLF and slope on the diversity of old-growth structures, oldgrowth forests must be defined using both temporal and environmental parameters. 
Table 4. Results of the regression analysis of the environmental and the temporal and structural parameters. The models that did not fulfil the assumptions are represented by the symbol "-" in the model results. Significance is represented by the following symbols: n.s. (not significant), ${ }^{*}$ ( $p$ value $\left.\leq 0.05\right),{ }^{* *}(p$ value $\leq 0.01$ ), $* * \star$ ( $p$ value $\leq 0.001)$. Coefficient of the independent variable is presented only when the results were significant. Parameter codes are found in Table 1.

\begin{tabular}{lllllll}
$\begin{array}{l}\text { Structural } \\
\text { parameter }\end{array}$ & \multicolumn{2}{l}{ Model result } & & & \multicolumn{3}{l}{ Coefficient of the independent variables } \\
& $F$ & $R^{2}$ & significance & SL & MTSLF & SL $\times$ MTSLF \\
\hline TD & 2.15 & 0.09 & n.s. & & \\
SD & 3.18 & 0.12 & $*$ & & \\
BA & 4.36 & 0.16 & $* *$ & & \\
BFP & 14.88 & 0.40 & $* * *$ & $1.88 \mathrm{e}-02^{*}$ & \\
CWD & 14.72 & 0.40 & $* * *$ & & $4.13 \mathrm{e}-03^{* * *}$ \\
WSP & 7.77 & 0.27 & $* * *$ & & $-8.03 \mathrm{e}-04^{* *}$ \\
GF & 5.78 & 0.21 & $* * *$ & $-1.47 \mathrm{e}-02^{*}$ & \\
MH & 13.75 & 0.38 & $* * *$ & & $1.67 \mathrm{e}-02^{* *}$ \\
CBAP & 25.9 & 0.54 & $* *$ & & $3.96 \mathrm{e}-03^{* * *}$ \\
SI & - & - & - & &
\end{tabular}

\subsection{Structural dynamics of boreal old-growth forests}

We created three succession models of boreal old-growth succession, distinguished by the degree of slope: gentle slopes, medium slopes and steep slopes (Fig. 4). As all even-aged forest types were found in the gentle slope succession model, the types of even-aged stands that would have been at the initial stages of the other models were determined by examining the transition stand characteristics and the species composition of their coarse woody debris (Appendix B). However, these stands are purely theoretical and cannot be include in our typology, their purpose is therefore to simply clarify the succession models. The medium slope succession model starts with an even-aged black spruce stand situated on medium slopes while the high slope succession model begins with an even-aged broadleaved-black spruce-balsam fir mixture situated on steep slopes. The absence of even-aged stands on the steepest sites is consistent with previous suggestions that gap dynamics begin earlier in these conditions, potentially because of 
Fig 4. Ecological models of the successional dynamics of old-growth boreal forests in the study region. Brackets regroup old-growth forest types (Gr. = Group) passing through the same transition process. Grey stands without group identification and a name written in italic represent theoretical even-aged structures starting the medium slope and high slope succession. The five silhouettes at the top of the figure are reproduced with permission from Natural Resources Canada, Canadian Forest Service, https://tidcf.nrcan.gc.ca/en/trees, 2017.

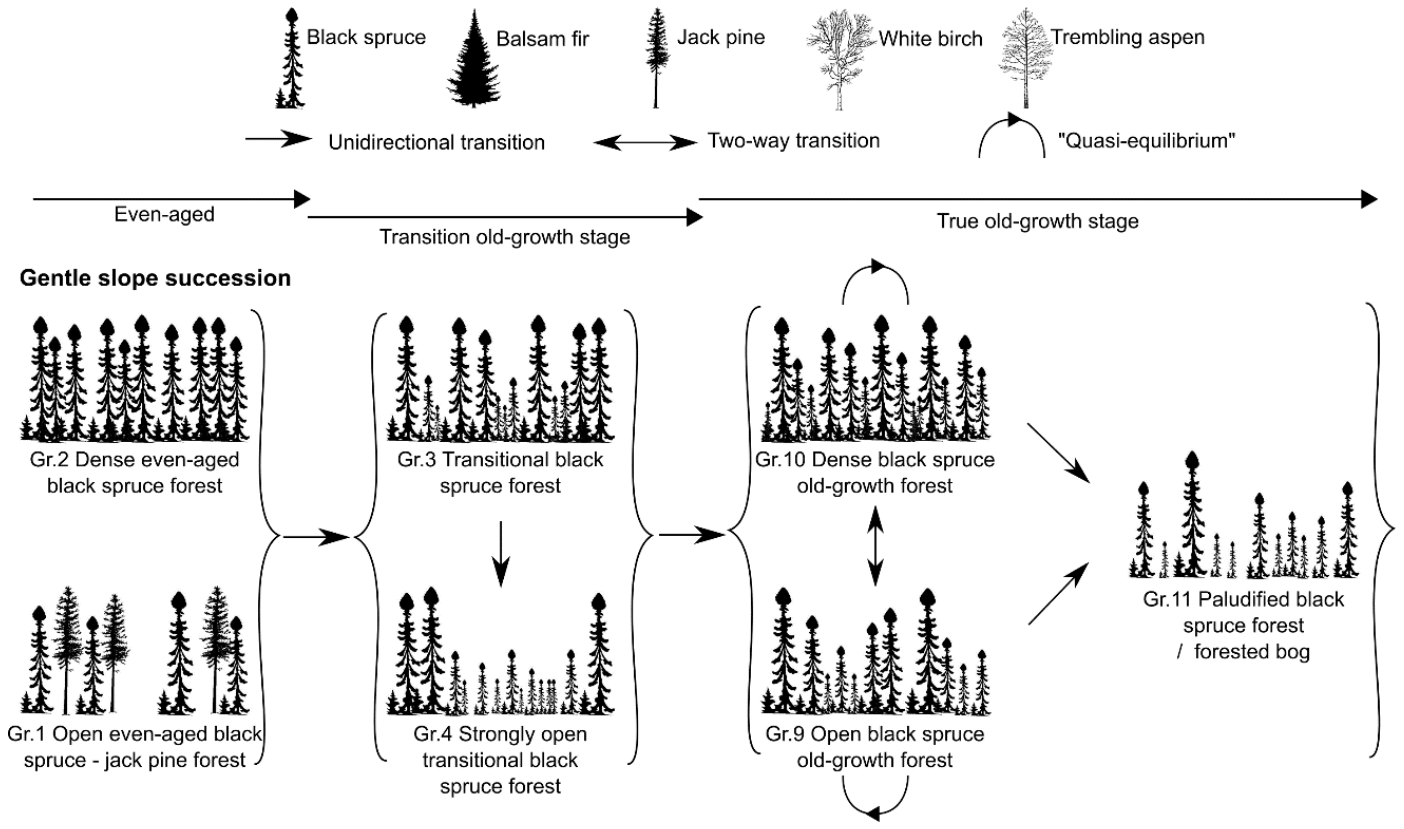

Medium slope succession

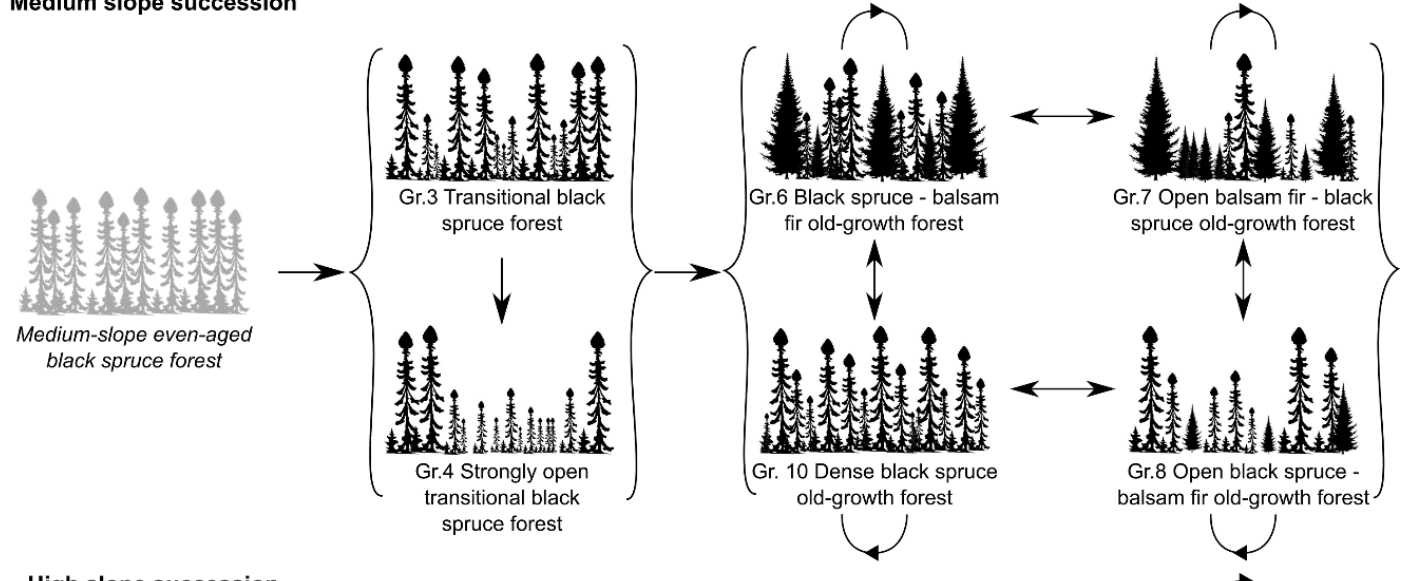

High slope succession

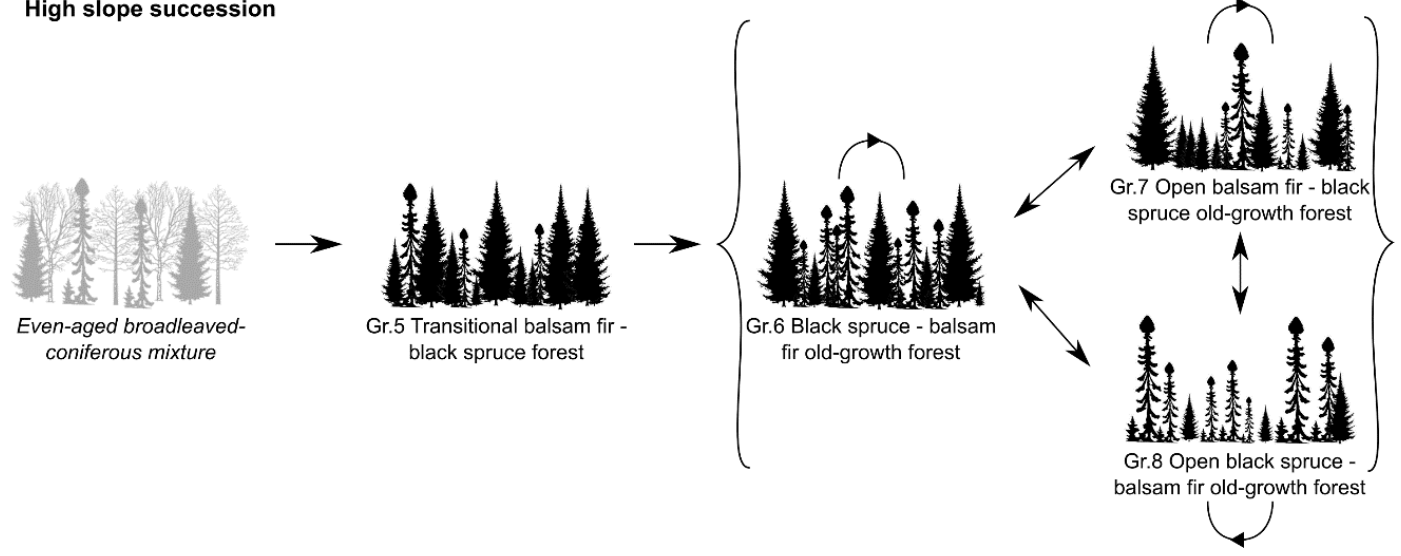


their higher sensitivity to secondary disturbance (Uhlig et al. 2001; Gauthier et al. 2010). Among the transition old-growth forests, Group 5 is specific to the steep slope succession model, but Group 3 and Group 4 can be found in both gentle and medium slope succession models. These last two forest types represent moderate (Group 3) and a strong (Group 4) canopy break-up. Group 4 appears to represent a specific case found in black spruce stands, where canopy break-up starts at an older age (Mean time since last fire $>200$ years) or when transition old-growth stands are affected by an abnormally strong secondary disturbance. This results in an important punctual rather than gradual mortality event that may occur due to the susceptibility of a stand dominated by old, tall and evenaged black spruce to stem breakage and windthrow (Robichaud and Methven 1993; Pothier et al. 1995).

Once the true old-growth stage is reached, stand structures are still considered as dynamic, since diverse secondary disturbances and the effective regeneration of black spruce and balsam fir under a canopy in non-paludified contexts keep structural types changing through time (Pham et al. 2004; McCarthy and Weetman 2006; Girard et al. 2014). In contrast, the dynamics of paludified stands inhibit any transition toward another true old-growth structure as tree regeneration is suppressed in the absence of fire (Fenton et al. 2005; Fenton and Bergeron 2011). Among our forest types, Group 11 is considered as representing forested bogs and paludified forests because of its strong depth of the organic horizon and gap fraction coupled with low basal area and maximum height values. Consequently, this is the only true old-growth structure connected to the others by a unidirectional link. All other true old-growth structures can evolve along a coarse woody debris/balsam fir proportion and basal area/gap fraction gradient or maintain a relatively homogeneous structure, depending on secondary disturbance dynamics. Slope then defines which structure can be connected to another, all of them covering two succession models except for Gr.9 and Gr.11, which are specific to gentle slope succession. 
Consequently, true boreal old-growth forests in Eastern Canada present a variety of structures and compositions, mainly determined by topography and secondary disturbance dynamics.

Eastern white cedar (Thuja occidentalis L.) and white spruce (Picea glauca (Moench) Voss), the two other late-successional species in Eastern Canada (Harvey et al. 2002), are almost absent in our study territory. In addition, Eastern Canada is not a totally homogeneous territory, presenting particular geomorphologic properties, such as the Clay-Belt region dominated by clay soils rather than tills (Harper et al. 2003; Lecomte and Bergeron 2005; Bergeron and Harper 2009), or particular climatic conditions, such as the moist maritime climates at the eastern edge of Canada (Bouchard and Pothier 2011; Kneeshaw et al. 2011). The identified structures are consequently unlikely to represent all the structural diversity of Eastern Canadian boreal old-growth forests but represent a regional subset of the whole. At a larger scale, these structures cannot be generalized to territories defined by other climatic conditions, disturbance dynamics and species traits (Shorohova et al. 2008; Kneeshaw et al. 2011; Shorohova et al. 2011). Despite this, black spruce dominated stands or black spruce - balsam fir mixtures are the main latesuccessional forest formations in Eastern Canadian boreal forest (De Grandpré et al. 2000; Bouchard et al. 2008; Gauthier et al. 2010), and our work therefore provides a pertinent analysis of the boreal old-growth diversity and internal dynamics in Eastern Canada. Furthermore, our study underlines the importance in identifying the structural richness of boreal old-growth forests at a fine scale, as these complex ecosystems should not be considered as a uniform entity, even in a seemingly homogeneous landscape.

\subsection{Implications for management}

Different propositions have been made to better preserve old-growth forests or their structural attributes under forest management. The most common proposals involve 
conservation, using partial cuts, extending forest rotations or reducing harvesting rate (Bauhus et al. 2009; Ruel et al. 2013; Bouchard and Garet 2014). Our study could help researchers and managers to identify various type of old-growth in order to develop management practices adapted to old-growth forest conservation. Our results suggest that true old-growth structures exist before all the first cohort dies, and that old-growth stands can stay productive on till soils. Thus, extending forest rotations can be an efficient management solution, especially when considering that temporal continuity is an important component for old-growth forest biodiversity (Spies 2004; Schmiegelow and Monkkonen 2009; Fenton and Bergeron 2011).Partial cuts are often considered effective for conserving old-growth elements in managed stands as they can be applied with different objectives and different retention levels (Harvey et al. 2002; Bauhus et al. 2009; Kuuluvainen 2009). Their adaptability could allow the application of these treatments to maintain the main structural features of old-growth stands or to create similar structural transitions that are highlighted by our study.

When considering the structural characteristics of the forest types identified by our study, we observe strong variations in tree density, basal area and maximum height, implying important differences in wood volume and quality. One of the main limits for a broader development of alternatives to clearcutting is their economic viability (Ruel et al. 2013; Bose et al. 2014; Tahvonen and Rämö 2016), and these discrepancies in economic value may restrict their application for all the old-growth structures. An additional limit is the differences in technical applicability of alternative treatments depending on the stand characteristics. For instance, partial cuts can negatively affect stand structures, by aggravating a preexisting paludification process or causing strong windthrow mortality (Ruel et al. 2013; Bose et al. 2014). Nevertheless, the responsibility of the abundant use of clearcutting in the erosion of old-growth stands and the homogenization of the landscape has been largely admitted (Östlund et al. 1998; Haeussler and Kneeshaw 2003; 
Boucher and Grondin 2012). In addition, in a clearcutting dominated scenario, it is likely that the remnant old-growth stands will be those with a lesser economic value because of a priorization of short-term profitability (Haeussler and Kneeshaw 2003; Ruel et al. 2013). These two last points are contradictory with the aims of natural base-management, where remnant stands in a managed territory must be representative of the preindustrial forest (Kuuluvainen 2002; Gauthier et al. 2009). Therefore, despite the limits previously observed for clearcutting alternatives, a shift must be done in the management of boreal old-growth forests. The preservation of the structural diversity in managed territories should require a particular attention and the development of less intensive treatments adapted to stand specificities should be prioritized. By providing a structural differentiation of boreal old-growth forests in Eastern Canada, our study present reliable guidelines for a better preservation of the structural diversity of old-growth forests in managed landscapes. On a larger scale, it demonstrates that the recognition of the structural diversity and dynamic of boreal old-growth forests is a prior issue for an efficient preservation of these ecosystems.

\section{Conclusion}

Boreal old-growth forests in Eastern Canada do not represent uniform stands but rather reflect a diversity of structures and variable amounts of black spruce and balsam fir. This distribution of old-growth structures across the landscape is partially determined by temporal and environmental conditions, with slope and minimum time since the last fire as the principal determinants defining the possible structural trajectories of an aging stand. Moreover, even when the true old-growth stage is reached, old-growth boreal forests remain dynamic, as structural changes occur dictated by secondary disturbance characteristics and stand attributes. Therefore, this diversity and the dynamics of boreal old-growth forests must be integrated into forest management planning to ensure an 
efficient preservation of these ecosystems after logging. Among the principal parameters differentiating old-growth structures, the proportion of balsam fir and gap fraction could be identified from cartographic surveys, but further studies need to be undertaken to determine the effectiveness of such an approach. Furthermore, the transition processes between true old-growth structural types remain unknown, and complementary work should be completed to better understand the dynamics of these ecosystems.

\section{Acknowledgements}

We thank Audrey Bédard, Jean-Guy Girard, Émilie Chouinard, Miguel Montoro Girona, Anne-Élizabeth Harvey, Aurélie Cuvelière, Évelyn Beliën and Angelo Fierravanti for their precious help during field sampling. Yan Boucher and Pierre Grondin from the Ministry of Forests, Wildlife and Parks (MWFP) shared their data collected from the study territory. Natural Resources Canada and Forest Service Direction gave permission for using their illustrations in this paper. Yan Boucher and two anonymous reviewers provided helpful comments on earlier version of this article. Funding for this project was provided by the Fonds Québécois de la Recherche sur la Nature et les Technologies (FQRNT) and the Natural Sciences and Engineering Research Council of Canada (NSERC) - Université du Québec à Chicoutimi (UQAC) industrial research chair "Chaire de recherche industrielle du CRSNG sur la croissance de l'épinette noire et l'influence de la tordeuse des bourgeons de l'épinette sur la variabilité des paysages en zone boréale". 


\section{References}

Armstrong, G. W. (1999). A stochastic characterisation of the natural disturbance regime of the boreal mixedwood forest with implications for sustainable forest management. Canadian Journal of Forest Research, 29(4), 424-433. https://doi.org/10.1139/x99-010

Bailey, R. L., Dell, R. (1973). Quantifying diameter distributions with the Weibull function. Forest Sciences, 19(2), 97-104.

Battles, J. J., Dushoff, J. G., Fahey, T. J. (1996). Line intersect sampling of forest canopy gaps. Forest Science, 42(2), 131-138.

Bauhus, J., Puettmann, K., Messier, C. (2009). Silviculture for old-growth attributes. Forest Ecology and Management, 258(4), 525-537.

https://doi.org/10.1016/i.foreco.2009.01.053

Berg, A., Ehnström, B., Gustafsson, L., Hallingbäck, T., Jonsell, M., Weslien, J. (1994). Threatened plant, animal, and fungus species in Swedish forests - Distribution and habitat associations. Conservation Biology, 8(3), 718-731.

https://doi.org/10.1046/j.1523-1739.1994.08030718.x

Bergeron, J-F, Grondin, P., Blouin, J. (1998). Rapport de classification écologique du sous-domaine bioclimatique de la pessières à mousses de l'ouest. Ministère des Ressources naturelles du Québec, Direction des inventaires forestiers. 204 p.

Bergeron, Y. Harper, K.A. (2009). Old-growth forests in the Canadian boreal: the exception rather than the rule? In: Wirth, C., Gleixner, G., Heimann, M. (eds.), OldGrowth Forests: Function, Fate and Value, Ecological Studies 207, Springer, New York, pp. 285-300.

Bergeron, Y., Leduc, A., Harvey, B. D., Gauthier, S. (2002). Natural fire regime: A guide for sustainable management of the Canadian boreal forest. Silva Fennica, 36, 81-95.

Bergeron, Y., Cyr, D., Drever, C. R., Flannigan, M., Gauthier, S., Kneeshaw, D., Lauzon, E., Leduc, A., Le Goff, H., Lesieur, D., Logan, K. (2006). Past, current, and future fire frequencies in Quebec's commercial forests: implications for the cumulative effects of harvesting and fire on age-class structure and natural disturbance-based management. Canadian Journal of Forest Research, 36(11), 2737-2744. https://doi.org/10.1139/x06$\underline{177}$

Black, B., Abrams, M. (2003). Use of boundary-line growth patterns as a basis for dendroecological release criteria. Ecological Applications, 13(6), 1733-1749.

Blouin, J. Berger, J.-P. (2004). Guide de reconnaissance des types écologiques des régions écologiques $6 c$ - Plaine du lac Opémisca, $6 \mathrm{~d}$ - Coteaux du lac Assinica, 6e Coteaux de la rivière Nestaocano, $6 f$ - Coteaux du lac Mistassini et $6 g$ - Coteaux du lac Manouane, ministère des Ressources naturelles, de la Faune et des Parcs, Forêt Québec, Direction des inventaires forestiers, Division de la classification écologique et productivité des stations. 
Borcard, D., Gillet, F., Legendre, P. (2011). Numerical Ecology with R. UseR! Series. Springer, NY. 306 p.

Bose, A. K., Harvey, B. D., Brais, S., Beaudet, M., Leduc, A. (2014). Constraints to partial cutting in the boreal forest of Canada in the context of natural disturbance-based management: A review. Forestry, 87(1), 11-28. https://doi.org/10.1093/forestry/cpt047

Bouchard, M., Pothier, D., Gauthier, S. (2008). Fire return intervals and tree species succession in the North Shore region of eastern Quebec. Canadian Journal of Forest Research, 38(6), 1621-1633. https://doi.org/10.1139/X07-201

Bouchard, M., Garet, J. (2014). A framework to optimize the restoration and retention of large mature forest tracts in managed boreal landscapes. Ecological Applications, 24(7), 1689-1704.

Bouchard, M., Pothier, D. (2011). Long-term influence of fire and harvesting on boreal forest age structure and forest composition in eastern Québec. Forest Ecology and Management, 261(4), 811-820. https://doi.org/10.1016/j.foreco.2010.11.020

Boucher, D., De Grandpré, L., Gauthier, S. (2003). Développement d'un outil de classification de la structure des peuplements et comparaison de deux territoires de la pessière à mousses du Québec. The Forestry Chronicle, 79(2), 318-328.

https://doi.org/10.5558/tfc79318-2

Boucher, D., De Grandpré, L., Kneeshaw, D., St-Onge, B., Ruel, J.-C., Waldron, K., Lussier, J.-M. (2015). Effects of 80 years of forest management on landscape structure and pattern in the eastern Canadian boreal forest. Landscape Ecology, 30,1913-1929. https://doi.org/10.1007/s10980-015-0220-6

Boucher, Y., Grondin, P. (2012). Impact of logging and natural stand-replacing disturbances on high-elevation boreal landscape dynamics (1950-2005) in eastern Canada. Forest Ecology and Management, 263, 229-239.

https://doi.org/10.1016/i.foreco.2011.09.012

Brassard, B. W., Chen, H. Y. H. (2006). Stand structural dynamics of North American boreal forests. Critical Reviews in Plant Sciences, 25(2), 115-137. https://doi.org/10.1080/07352680500348857

Burns, R.M., Honkala, B.H. (1990) Silvics of North America: 1. Conifers; 2. Hardwoods. Agriculture Handbook 654, Forest Service, United States Department of Agriculture, Washington, DC. 877 p.

Clark, D. F., Kneeshaw, D. D., Burton, P. J., Antos, J. A. (1998). Coarse woody debris in sub-boreal spruce forests of west-central British Columbia. Canadian Journal of Forest Research, 28(2), 284-290. https://doi.org/10.1139/x97-208

Côté, S. (2013). Le sapin baumier. In: Ministère des Ressources Naturelles (ed.) Le guide sylvicole du Québec, T. 1. Les fondements biologiques de la sylviculture. Les Publications du Québec, Québec. 1044 p. 
Cyr, D., Gauthier, S., Bergeron, Y., Carcaillet, C. (2009). Forest management is driving the eastern North American boreal forest outside its natural range of variability. Frontiers in Ecology and the Environment, 7(10), 519-524. https://doi.org/10.1890/080088

Esseen, P.-A., Ehnström, B., Ericson, L. Sjöberg, K. (1997). Boreal forests. Ecological Bulletins, 46, 16-47.

Etheridge, D. A., MacLean, D. A., Wagner, R. G., Wilson, J. S. (2006). Effects of intensive forest management on stand and landscape characteristics in northern New Brunswick, Canada (1945-2027). Landscape Ecology, 21(4), 509-524.

https://doi.org/10.1007/s10980-005-2378-9

Fenton, N., Lecomte, N., Légaré, S., Bergeron, Y. (2005). Paludification in black spruce (Picea mariana) forests of eastern Canada: Potential factors and management implications. Forest Ecology and Management, 213(1-3), 151-159.

https://doi.org/10.1016/j.foreco.2005.03.017

Fenton, N. J., Bergeron, Y. (2011). Dynamic old-growth? A case study of boreal black spruce forest bryophytes. Silva Fennica, 45(5), 983-994.

Franklin, J.F., Spies, T.A., Pelt, R.V., Carey, A.B., Thornburgh, D.A., Berg, D.R., Lindenmayer, D.B., Harmon, M.E., Keeton, W.S., Shaw, D.C., Bible, K., Chen, J. (2002). Disturbances and structural development of natural forest ecosystems with silvicultural implications, using Douglas-fir forests as an example. Forest Ecology and Management, 155, 399-423. https://doi.org/10.1016/S0378-1127(01)00575-8

Fraver, S., White, A. S. (2005). Identifying growth releases in dendrochronological studies of forest disturbance. Canadian Journal of Forest Research, 35(7), 1648-1656. https://doi.org/10.1139/x05-092

Fraver, S., Jonsson, B. G., Jönsson, M., Esseen, P.-A. (2008). Demographics and disturbance history of a boreal old-growth Picea abies forest. Journal of Vegetation Science, 19(6), 789-798. https://doi.org/10.3170/2008-8-18449

Gauthier, S., Vaillancourt, M.-A., Leduc, A., Grandpré, L.D., Kneeshaw, D., Morin, H., Drapeau, P., Bergeron, Y. (2009). Ecosystem Management in the Boreal Forest. Presses de l'Université du Québec, Québec. 572p.

Gauthier, S., Boucher, D., Morissette, J., De Grandpré, L. (2010). Fifty-seven years of composition change in the eastern boreal forest of Canada. Journal of Vegetation Science, 21(4), 772-785. https://doi.org/10.1111/j.1654-1103.2010.01186.x

Garet, J., Raulier, F., Pothier, D., Cumming, S. G. (2012). Forest age class structures as indicators of sustainability in boreal forest: Are we measuring them correctly? Ecological Indicators, 23, 202-210. https://doi.org/10.1016/..ecolind.2012.03.032

Girard, F., De Grandpré, L., Ruel, J. C. (2014). Partial windthrow as a driving process of forest dynamics in old-growth boreal forests. Canadian Journal of Forest Research, 44(10), 1165-1176. https://doi.org/10.1139/cifr-2013-0224 
De Grandpré, L., Morissette, J., Gauthier, S. (2000). Long-term post-fire changes in the northeastern boreal forest of Quebec. Journal of Vegetation Science, 11(6), 791-800.

De Grandpré, L., Gauthier, S., Allain, C., Cyr, D., Périgon, S., Pham, A.T., Boucher, D., Morissette, J., Reyes, G., Aakala, T. Kuuluvainen T. (2008). Vers un aménagement écosystémique de la forêt boréale de la Côte-Nord : régime des perturbations et dynamique naturelle. In: Gauthier, S., Vaillancourt, M.-A., Leduc, A., De Grandpré, L., Kneeshaw, D., Morin, H., Drapeau P. Bergeron, Y. (eds.). Aménagement écosystémique en forêt boréale. Presses de l'Université du Québec, Québec, QC. pp. 241-268.

Haeussler, S., Kneeshaw, D. (2003). Comparing forest management to natural processes. In: Burton, P.J., Messier, C., Smith, C., Adamowicz, W.L. (eds.), Towards Sustainable Management of the Boreal Forest. NRC Research Press, Ottawa, Ont., pp. 307-368.

Halme, P., Allen, K.A., Auniņš, A., Bradshaw, R.H.W., Brumelis, G., Čada, V., Clear, J.L.,Eriksson, A.-M., Hannon, G., Hyvärinen, E., Ikauniece, S., Iršènaitė , R., Jonsson, B.G., Junninen, K., Kareksela, S., Komonen, A., Kotiaho, J.S., Kouki, J., Kuuluvainen, T., Oldén, A., Mazziotta, A., Mönkkönen, M., Nyholm, K., Shorohova, E., Strange, N., Toivanen, T., Vanha-Majamaa, I., Wallenius, T., Ylisirniö, A.-L., Zin, E (2013).

Challenges of ecological restoration: Lessons from forests in northern Europe. Biological Conservation, 167, 248-256. https://doi.org/10.1016/j.biocon.2013.08.029

Harvey, B. D., Leduc, A., Gauthier, S., Bergeron, Y. (2002). Stand-landscape integration in natural disturbance-based management of the southern boreal forest. Forest Ecology and Management, 155(1-3), 369-385. https://doi.org/10.1016/S0378-1127(01)00573-4

Hilbert, J., Wiensczyk, A. (2007). Old-growth definitions and management: A literature review. BC Journal of Ecosystems and Management, 8(1), 15-32.

Kneeshaw, D.D., Burton, P.J. (1998). Assessment of functional old-growth status: a case study in the sub-boreal spruce zone of British Columbia, Canada. Natural Areas Journal, 18: 293-308.

Kneeshaw, D., Gauthier, S. (2003). Old growth in the boreal forest: A dynamic perspective at the stand and landscape level. Environmental Reviews, 11(S1), S99S114. https://doi.org/10.1139/a03-010

Kneeshaw, D., Bergeron, Y., Kuuluvainen, T. (2011). Forest ecosystem structure and disturbance dynamics across the circumboreal forest. In A. C. Millington (Ed.), The SAGE Handbook of biogeography, London: Sage, pp. 261-278.

Kuuluvainen, T. (2002). Natural variability of forests as a reference for restoring and managing biological diversity in boreal Fennoscandia. Silva Fennica, 36(1), 97-125. https://doi.org/10.1579/08-A-490.1

Kuuluvainen, T. (2009). Forest Management and Biodiversity Conservation Based on Natural Ecosystem Dynamics in Northern Europe: The Complexity Challenge. Ambio, 38(6), 309-315. 
Laamrani, A., Valeria, O., Bergeron, Y., Fenton, N., Cheng, L. Z., Anyomi, K. (2014). Effects of topography and thickness of organic layer on productivity of black spruce boreal forests of the Canadian clay belt region. Forest Ecology and Management, 330, 144-157. https://doi.org/10.1016/j.foreco.2014.07.013

Lavoie, M., Paré, D., Fenton, N., Groot, A., Taylor, K. (2005). Paludification and management of forested peatlands in Canada: a literature review. Environmental Reviews, 13(2), 21-50.

Le Goff, H., De Grandpré, L., Kneeshaw, D., Bernier, P. (2010). L'aménagement durable des vieilles forêts boréales: mythes, pistes de solutions et défis. The Forestry Chronicle, 86(1), 63-69. https://doi.org/10.5558/tfc86063-1

Le, S., Josse, J., Husson, F. (2008). FactoMineR: An R Package for Multivariate Analysis. Journal of Statistical Software, 25(1), 1-18.

Lecomte, N., Bergeron, Y. (2005). Successional pathways on different surficial deposits in the coniferous boreal forest of the Quebec Clay Belt. Canadian Journal of Forest Research, 35(8), 1984-1995. https://doi.org/10.1139/x05-114

Lecomte, N., Simard, M., Bergeron, Y. (2006). Effects of fire severity and initial tree composition on stand structural development in the coniferous boreal forest of northwestern Québec, Canada. Écoscience, 13(2), 152-163.

https://doi.org/10.2980/i1195-6860-13-2-152.1

Maechler, M., Rousseeuw, P., Struyf, A., Hubert, M., Hornik, K. (2017). Cluster: Cluster Analysis Basics and Extensions. R package version 2.0.6.

Marshall, P.L., Davis, G., LeMay, S.W. (2000). Using Line Intersect Sampling for Coarse Woody Debris. Research Section, Vancouver Forest Region, BC Ministry of Forests. 34 p.

McCarthy, J. W., Weetman, G. (2006). Age and size structure of gap-dynamic, oldgrowth boreal forest stands in Newfoundland. Silva Fennica, 40(2), 209-230.

de Mendiburu. F. (2017). Agricolae: Statistical Procedures for Agricultural Research. R package version 1.2-8.

Messaoud, Y., Bergeron, Y., Leduc, A. (2007). Ecological factors explaining the location of the boundary between the mixedwood and coniferous bioclimatic zones in the boreal biome of eastern North America. Global Ecology and Biogeography, 16(1), 90-102. https://doi.org/10.1111/j.1466-8238.2006.00277.x

Messaoud, Y., Asselin, H., Bergeron, Y., Grondin, P. (2014). Competitive Advantage of Black Spruce Over Balsam Fir in Coniferous Boreal Forest of Eastern North America Revealed by Site Index. Forest Science, 60(1), 57-62.

Ministère des Ressources Naturelles (2013). Norme de Stratification Écoforestière Quatrième inventaire Écoforestier du Québec Méridional. Direction des inventaires forestiers. $101 \mathrm{p}$. 
Ministère de la Forêt, de la Faune et des Parcs (MFFP) (2016). Norme d'inventaire écoforestier - Placette-échantillons temporaires. Direction des inventaires forestiers, Québec 172p.

Mosseler, A., Thompson, I., Pendrel, B. A. (2003). Overview of old-growth forests in Canada from a science perspective. Environmental Reviews, 11(S1), S1-S7. https://doi.org/10.1139/a03-018

Nguyen, T. (2002). Développement d'une stratégie d'aménagement forestier s'inspirant de la dynamique des perturbations naturelles pour la région Nord de l'Abitibi (année 3). Rapport de recherche effectuée dans le cadre du Volet 1 du programme de mise en valeur des ressources du milieu forestier. Université du Québec en AbitibiTémiscamingue, Rouyn-Noranda, Qc. 14 p.

Oksanen, J., Blanchet, F.G., Kindt, R., Legendre, P., Minchin, P.R., O'Hara, R.B., Simpson, G.L., Solymos, P., Stevens, M.H.H., Wagner, H. (2017). VEGAN: community ecology package. $\mathrm{R}$ package version 2.4-3.

Oliver, C.D., Larson, B.C. (1996). Forest Stand Dynamics. John Wiley \& Sons, Inc., New York, Updated edition. 520 p.

Östlund, L., Zackrisson, O., Axelsson, A.-L. (1997). The history and transformation of a Scandinavian boreal forest landscape since the 19th century. Canadian Journal of Forest Research, 27(8), 1198-1206. https://doi.org/10.1139/x97-070

Pesklevits, A., Duinker, P. N., Bush, P. G. (2011). Old-growth forests: Anatomy of a wicked problem. Forests, 2(1), 343-356. https://doi.org/10.3390/f2010343

Pham, A. T., Grandpré, L. De, Gauthier, S., Bergeron, Y. (2004). Gap dynamics and replacement patterns in gaps of the northeastern boreal forest of Quebec. Canadian Journal of Forest Research, 34(2), 353-364. https://doi.org/10.1139/x03-265

Pollock, S. L., Payette, S. (2010). Stability in the patterns of long-term development and growth of the Canadian spruce-moss forest. Journal of Biogeography, 37(9), 1684-1697. https://doi.org/10.1111/j.1365-2699.2010.02332.x

Pothier, D., Doucet, R., Boily, J. (1995). The effect of advance regeneration height on future yield of black spruce stands. Canadian Journal of Forest Research, 25, 536-544.

R Development Core Team (2017). R: A language and environment for statistical computing. R Foundation for Statistical Computing, Vienna, Austria. URL http://www.Rproject.org/.

Robichaud, E., Methven, I. R. (1993). The effect of site quality on the timing of stand breakup, tree longevity, and the maximum attainable height of black spruce. Canadian Journal of Forest Research, 23(8), 1514-1519.

Rousseeuw, P. J. (1987). Silhouettes: a graphical aid to the interpretation and validation of cluster analysis. Journal of Computational and Applied Mathematics, 20, 53-65. 
Ruel, J. (2000). Factors influencing windthrow in balsam fir forests: from landscape studies to individual tree studies. Forest Ecology and Management, 135(1-3), 169-178.

Ruel, J.-C., Fortin, D., Pothier, D. (2013). Partial cutting in old-growth boreal stands: An integrated experiment. The Forestry Chronicle, 89(3), 360-369. https://doi.org/10.5558/tfc2013-066

Runkle, J. R. (1982). Patterns of disturbance in some old-growth mesic forests of eastern North America. Ecology, 63(5), 1533-1546.

Schmiegelow, F. K. A., Monkkonen, M. (2009). Habitat loss and fragmentation in dynamic landscapes: avian perspectives from the boreal forest. Ecological Applications, 12(2), 375-389.

Schulze, E.-D., Hessenmoeller, D., Knohl, A., Luyssaert, S., Boerner, A., Grace, J. (2009) Temperate and boreal old-growth forests : How do their growth dynamics and biodiversity differ from young stands and managed forests In: Wirth, C., Gleixner, G., Heimann, M. (eds.), Old-Growth Forests: Function, Fate and Value, Ecological Studies 207., Springer, New York, pp. 343-366.

Shannon, C.E., Weaver, W. (1949). The Mathematical Theory of Communication. University of Illinois Press, Urbana. $117 \mathrm{p}$.

Shorohova, E., Kneeshaw, D., Kuuluvainen, T., Gauthier, S. (2011). Variability and Dynamics of Old- Growth Forests in the Circumboreal Zone: Implications for Conservation, Restoration and Management. Silva Fennica, 45(5), 785-806.

Shorohova, E., Kuuluvainen, T., Kangur, A., Jõgiste, K. (2009). Natural stand structures, disturbance regimes and successional dynamics in the Eurasian boreal forests: a review with special reference to Russian studies. Annals of Forest Science, 66(2), 201-201. https://doi.org/10.1051/forest/2008083

Siitonen, J. (2001). Forest management, coarse woody debris and saproxylic organisms: Fennoscandian boreal forests as an example. Ecological Bulletins, 49, 10-41.

Smirnova, E., Bergeron, Y., Brais, S. (2008). Influence of fire intensity on structure and composition of jack pine stands in the boreal forest of Quebec: Live trees, understory vegetation and dead wood dynamics. Forest Ecology and Management, 255, 29162927. https://doi.org/10.1016/.foreco.2008.01.071

Spies, T. A. (2004). Diversity of old-growth forests. Journal of Forestry, April/May, 1420.

St-Denis, A., Kneeshaw, D., Bergeron, Y. (2010). The role of gaps and tree regeneration in the transition from dense to open black spruce stands. Forest Ecology and Management, 259(3), 469-476. https://doi.org/10.1016/i.foreco.2009.11.002

Sturtevant, B. R., Bissonette, J. A., Long, J. N., Roberts, D. W., (1997). Coarse woody debris as a function of age, stand structure, and disturbance in boreal Newfoundland. Ecological Applications, 7(2), 702-712. 
Tahvonen, O., Rämö, J. (2016). Optimality of continuous cover vs. clear-cut regimes in managing forest resources. Canadian Journal of Forest Research, 46(7), 891-901. https://doi.org/10.1139/cjfr-2015-0474

Uhlig, P. A., Harris, G., Craig, C., Bowling, B., Chambers, B., Naylor, B. Beemer, G. (2001). Oldgrowth forest definitions for Ontario. Ontario Ministry of Natural Resources, (ed.) Queen's Printer for Ontario. 27 p.

Vanha-Majamaa, I., Lilja, S., Ryömä, R., Kotiaho, J. S., Laaka-Lindberg, S., Lindberg, H., Puttonen, P., Tamminen, P., Toivanen, T., Kuuluvainen, T. (2007). Rehabilitating boreal forest structure and species composition in Finland through logging, dead wood creation and fire: The EVO experiment. Forest Ecology and Management, 250, 77-88. https://doi.org/10.1016/i.foreco.2007.03.012

Viglas, J.N., Brown, C.D. Johnstone, J.F. (2013) Age and size effects on seed productivity of northern black spruce. Canadian Journal of Forest Research, 43, 534543

Ward, J.H. (1963). Hierarchical grouping to optimize an objective function. Journal of the American Statistical Association, 58, 236-244.

Ward, C., Pothier, D., Pare, D. (2014). Do boreal forests need fire disturbance to maintain productivity? Ecosystems, 17, 1053-1067. https://doi.org/10.1007/s10021-014$\underline{9782-4}$

Wirth, C., Messier, C., Bergeron, Y., Frank, D. Fankhänel, A. (2009). Old-growth forests definitions: a pragmatic view In: Wirth, C., Gleixner, G., Heimann, M. (eds.), Old-Growth Forests: Function, Fate and Value, Ecological Studies 207. Springer, New York, pp. 1133.

Zeileis, A., Hothorn, T. (2002). Diagnostic checking in regression relationships. $R$ News 2(3), 7-10. URL https://CRAN.R-project.org/doc/Rnews/ 


\section{Supplementary material}

Appendix A. Mean basal area proportion of the tree species for each forest type as defined by the hierarchical cluster analysis. $\mathrm{SP}=$ black and white spruce, $\mathrm{BF}=$ balsam fir, $\mathrm{JP}=$ jack pine and $\mathrm{BD}=$ broadleaved species.

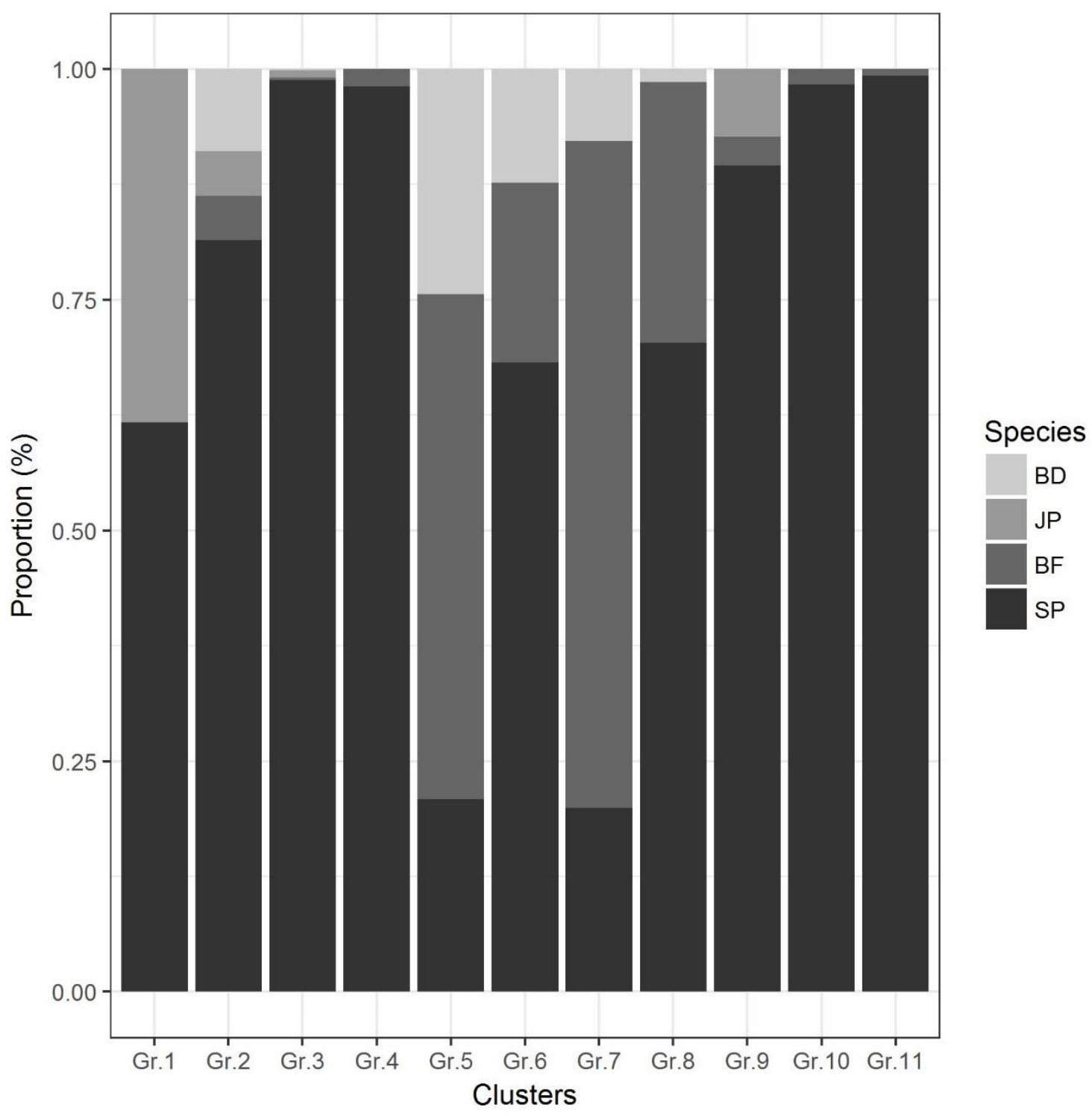


Appendix B. Mean coarse woody debris volume proportion of the tree species for each forest type as defined by the hierarchical cluster analysis. $\mathrm{SP}=$ black and white spruce, $\mathrm{BF}=$ balsam fir, $\mathrm{JP}=$ jack pine, $\mathrm{BD}=$ broadleaved species and $\mathrm{UNK}=$ unknown species.

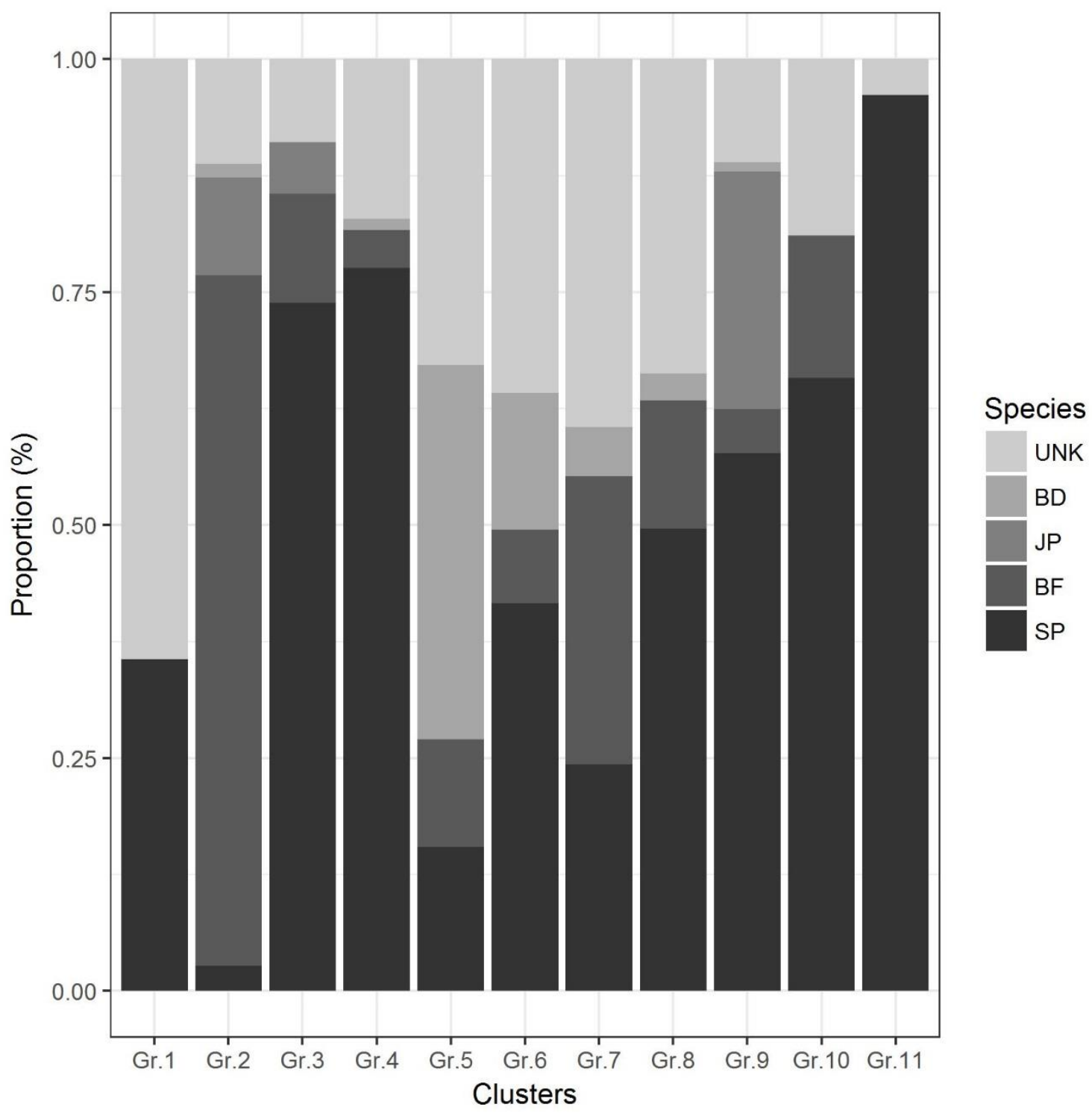

